\title{
PENGARUH PEMBERIAN JUS JAMBU BIJI MERAH DAN KURMA TERHADAP PENINGKATAN KADAR HB PADA IBU POST PARTUM
}

\author{
THE INFLUENCE OF RED GUAVA JUICE AND DATES TO ENHANCEMENT OF HB \\ LEVELS IN POST PARTUM MOTHER
}

\author{
Rini Anggeriani ${ }^{1}$, Mona Yatiliu ${ }^{2}$ \\ Sekolah Tinngi Ilmu Kesehatan Abdurahman Palembang, Jl. Sukajaya No.7 Kol. H.Burlian KM. 5,5 \\ Palembang, Sumatera Selatan, Indonesia \\ email: anggeriani_r@ymail.com ${ }^{1}$,yatilium@gmail.com ${ }^{2}$
}

\begin{abstract}
ABSTRAK
Data World Health Organization (WHO) tahun 2017 mengenai status kesehatan nasional pada capaian target Sustainable Development Goals (SDGs) menyatakan secara global sekitar 830 wanita meninggal setiap hari karena komplikasi selama kehamilan dan persalinan, dengan tingkat AKI sebanyak 216 per 100.000 kelahiran hidup. Sebanyak 99 persen kematian ibu akibat masalah kehamilan, persalinan atau nifas terjadi di negaranegara berkembang. Anemia adalah kondisi dimana berkurangnya sel darah merah (eritrosit) dalam sirkulasi darah atau massa hemoglobin sehingga tidak mampu memenuhi fungsinya sebagai pembawa oksigen keseluruh jaringan. Tujuan penelitian ini untuk mengetahui Pengaruh Pemberian Jus Jambu Biji Merah dan Kurma terhadap Peningkatan Kadar Hb pada Ibu Post Partum.Penelitian ini menggunakan desain penelitian preeksperiment dengan pendekatan one group pre-test post-test.Dengan pengambilan sampel dilakukan secara purposive sampling. Analisis data menggunakan analisis univariat, bivariat menggunakan uji paired t-test. Hasil penelitian menunjukkan bahwa 15 responden ibu post partum yang mengalami anemia didapatkan nilai $p$ value 0,000 $\leq$ 0,05 sehingga dapat disimpulkan bahwa ada pengaruh pemberian jus jambu biji merah dan kurma pada ibu post partum yang mengalami anemia. Diharapkan untuk ibu post partum yang anemia untuk mengkonsumsi jus jambu biji merah dan kurma secara rutin agar dapat meningkatkan kadar Hb dalam tubuh.
\end{abstract}

Kata Kunci : : Jus jambu biji merah dan kurma, kadar $\mathrm{Hb}$ ibu post partum

\begin{abstract}
The Data in 2017 from World Health Organization (WHO) on national health status at the target of the Sustainable Development Goals (SDGs) stated globally around 830 women die every day due to complications during pregnancy and childbirth, with an MMR rate of 216 per 100,000 live births. As much as 99 percent of maternal deaths due to problems of pregnancy, and childbirth or childbirth happened in developing countries. Anemia was a condition in which red blood cells (erythrocytes) decrease in the blood circulation or the mass of hemoglobin so that it was unable to fulfill its function as a carrier of oxygen throughout the tissue. The purpose of this study was to determine the effect of the administration of red guava juice and dates palm to increase Hb levels in post partum mothers. This study used a pre-experimental research design with a one group pre-test post-test approach. With sampling was taken by purposive sampling. The Data analysis using univariate, bivariate analysis using paired t-test. The results showed that 15 postpartum mothers who experienced anemia had a $p$ value of 0,000 $\leq 0.05$ so it can be concluded that there was an effect of giving red guava juice and dates to post partum mothers who had anemia. It is expected for post partum mothers who are anemic to consume red guava juice and dates routinely in order to increase Hb levels in the body.
\end{abstract}

Keywords: Red guava juice and dates, Hb levels of post partum mothers 


\section{PENDAHULUAN}

Data World Health Organization (WHO) mengenai status kesehatan nasional pada capaian target Sustainable Development Goals (SDGs) menyatakan secara global sekitar 830 wanita meninggal setiap hari karena komplikasi selama kehamilan dan persalinan, dengan tingkat AKI sebanyak 216 per 100.000 kelahiran hidup. Sebanyak 99 persen kematian ibu akibat masalah kehamilan, persalinan atau nifas terjadi di negara-negara berkembang.Rasio AKI masih dirasa cukup tinggi sebagaimana ditargetkan menjadi 70 per 100.000 kelahiran hidup pada tahun $2030^{1}$.

Berdasarkan data Kementrian Kesehatan Republik Indonesia (Kemenkes RI) tahun 2016, AKI menurun mencapai 305 kematian per $100.000 \mathrm{KH}$, lebihrendah jika dibandingkan dengan kondisi pada tahun tahun 2012 sebesar 359 kematian per $100.000 \mathrm{KH}^{2}$.

Berdasarkan Profil Kesehatan Provinsi Sumatera Selatan, AKI di Provinsi Sumatera Selatan pada tahun 2015 yaitu 165 per $100.000 \mathrm{KH}$, artinya AKI di Sumatera Selatan meningkat dibandingkan dengan tahun 2014 yaitu 155 per 100.000 KH. Jumlah kematian ibu tertinggi terjadi di Kabupaten Musi Banyuasin yaitu 20 kasus dan diikuti Kabupaten Ogan Komering Ilir (OKI) yaitu 18 kasus. Sedangkan jumlah kematian ibu terendah terjadi di kabupaten Pagar Alam yaitu 1 kasus. Jumlah kematian ibu di Provinsi Sumatera Selatan yang masih tinggi disebabkan oleh factor perdarahan dalam persalinan berjumlah 55 kasus, hipertensi dalam kehamilan berjumlah 34 kasus, disebabkan oleh penyakit infeksi berjumlah 6 kasus, faktor lain-lain berjumlah 55 kasus, oleh gangguan system peredaran darah berjumlah 30 kasus, dan factor gangguan metabolic berjumlah 4 kasus $^{3}$.
Berdasarkan Profil Kesehatan Kota Palembang, jumlah kematian ibu tahun 2017 dikota Palembang sebanyak 7 orang dari 27.875 KH. Jumlah tersebut mengalami penurunan jika dibandingkan dengan tahun 2016 sebanyak 10 orang dari $29.525 \mathrm{KH}$. Nilai ini masih dibawah target AKI nasional untuk RPJMN (Rencana Pembangunan Jangka Menengah Nasional) tahun 2016 sebesar 32/100.000 KH dari 7 kasus kematian ibu tersebut. Penyebabnya yaitu hipertensi dalam kehamilan $72 \%$ (5 orang) dan terendah adalah gangguan metabolism DM, yaitu sebanyak 1 orang dari sasaran 29.610 ibu hamil ditemukan 5.620 kasus ibu hamil, ibu bersalin, dan ibu nifas beresiko dan tersebut terhadap riwayat yang menderita hipertensi sebanyak 172 kasus $^{4}$.

Anemia adalah kondisi dimana berkurangnya sel darah merah (eritrosit) dalam sirkulasi darah atau massa hemoglobin sehingga tidak mampu memenuhi fungsinya sebagai pembawa oksigen keseluruh jaringan ${ }^{5}$.Tanda dan gejala anemia adalah keluhan lemah, pucat, mudah pingsan, sementara tensi masih dalam batas normal (perlu dicurigai anemia defisiensi), mengalami malnutrisi, cepat lelah, sering pusing, mata berkunangkunang, lidah luka, nafsu makan turun (anoreksia), konsentrasi hilang, nafas pendek (pada anemia parah) ${ }^{6}$.

Menurut Departemen Gizi dan Kesehatan Masyarakat (2011), penyebab utama anemia pada wanita adalah kurang memadainya asupan makanan sumber Fe, meningkatnya kebutuhan $\mathrm{Fe}$, meningkatkan kebutuhan $\mathrm{Fe}$ saat hamil dan menyusui (perubahan fisiologi), dan kehilangan banyak darah. Anemia yang disebabkan oleh ketiga faktor itu terjadi secara cepat cadangan Fe tidak mencukupi peningkatan kebutuhan Fe. Wanita usia subur (WUS) adalah salah satu kelompok resiko tinggi terpapar anemia karena mereka tidak memiliki asupan atau cadangan $\mathrm{Fe}$ yang 
cukup terhadap kebutuhan dan kehilangan Fe. Dari kelompok WUS tersebut yang paling tinggi resiko menderita anemia adalah wanita hamil, wanita nifas, dan wanita kehilangan darah saat menstruasi.Pada wanita yang mengalami menopause dengan defisiensi $\mathrm{Fe}$, yang menjadi penyebabnya adalah perdarahan gastrointestinal ${ }^{7}$.

Menurut Proverawati and Asfuah (2009), penyebab anemia yaitu makanan yang kurang bergizi, kurangnya zat besi dalam makanan, kehilangan darah banyak seperti persalinan yang lalu, haid dan lain-lain ${ }^{6}$.

Hemoglobin merupakan suatu protein yang kaya zat besi, memiliki afinitas (daya gabung) terhadap oksigen dan dengan oksigen itu membentuk oxihemoglobin didalam sel darah merah. Melalui fungsi ini maka oksigen dibawa dari paru-paru ke jaringan seluruh tubuh, jika kadar $\mathrm{Hb}$ $<12$ gr\% disebut anemia ${ }^{8}$.

Masanifas (puerperium) dimulai setelah plasenta lahir dan berakhir ketika alat kandungan kembali seperti keadaan sebelum hamil. Masa nifas dimulai sejak 2 jam setelah lahirnya plasenta sampai dengan 6 minggu (42 hari) setelah itu (Dewidan Sunarsih, 2011). Masa nifas (puerperium) adalah masa pulih kembali, mulai dari persalianan selesai hingga alatalat kandungan kembali seperti prahamil ${ }^{9}$.

Menurut Robson dan Waugh (2011), masalah yang terjadi pascapartum pada ibu yang anemia yaitu ibu berisiko mengalami perdarahan pascapartum, infeksi, buruknya pemulihan luka, depresi pascapartum, latergi, kesulitan menyusui ${ }^{10}$.

Menurut Prawirohardjo (2007), anemia dalam kehamilan memberi pengaruh kurang baik bagi ibu, baik dalam kehamilan, persalinan, maupun dalam nifas dan masa selanjutnya. Berbagai penyulit dapat timbul akibat anemia, seperti abortus,partus prematurus, partus lama karena anertia uteri, perdarahan postpartum karena atonia uteri, syok, infeksi, baik intrapartum maupun postpartum, anemia yang sangat berat dengan $\mathrm{Hb}$ kurang dari 4 gr\% dapat menyebabkan dekompensasi $\operatorname{kordis}^{11}$.

Akibat yang akan terjadi pada anemia kehamilan yaitu pada pascapartum perdarahan, retensio plasenta, perlukaan sukar sembuh, mudah terjadi febris peurperalis, gangguan involusi uteri, kematian ibu tinggi (perdarahan, infeksi peurperalis, gestosis ${ }^{6}$.

Salah satu buah yang dapat meningkatkan kadar hemoglobin adalah buah jambu biji dan menurut Muslihah(2010), kandungan zat kimia dalam jambu biji adalah asam amino (triptofan, lisin), kalsium, fosfor, besi, belerang, vitamin A, vitamin B1, dan vitamin C. Kandungan mineral yang ada dalam buah jambu biji dapat mengatasi penderita anemia (kekurangan darah merah) karena didalam buah jambu biji merah mengandung juga zat mineral yang dapat memperlancar proses pembentukan hemoglobin sel darah merah ${ }^{12}$.

Jambu biji mengandung berbagai zat gizi yang dapat digunakan sebagai obat untuk menyembuhkan penyakit. Kandungan lengkap kadar gizi yang terdapat dalam 100 gram jambu masak segar adalah protein sebanyak 0,9 gr, lemak 0,3 gr, karbohidrat $12,2 \mathrm{gr}$, kalsium $14 \mathrm{gr}$, fosfor $28 \mathrm{mg}$, besi $1,1 \mathrm{mg}$, vitamin A $25 \mathrm{SI}$, vitamin $\mathrm{B}_{1} 0,02$ $\mathrm{mg}$, vitamin C $87 \mathrm{mg}$, dan air 86 gr dengan total kalori sebanyak 49 kalori $^{13}$.

Buah jambu biji bermanfaat untuk pengobatan bermacam-macam penyakit, seperti memperlancar pencernaan, menurunkan kolesterol, antioksidan, menghilangkan rasa lelah dan lesu, demam berdarah dan sariawan ${ }^{14}$. 
Buah jambu biji merah mengandung senyawa yang dapat meningkatkan kadar hemoglobin dalam darah, antara lain: zat besi, vitamin $\mathrm{C}$, vitamin $\mathrm{A}$, tembaga dan fosfor. Zat besi merupakan mineral yang diperlukan untuk mengangkut oksigen ke seluruh tubuh.Kekurangan zat besi dalam tubuh bisa membuat seseorang mengalami penurunan sistem kekebalan tubuh dan sering merasa lesu.Hal ini juga merupakan salah satu penyebab anemia, zat besi dengan vitamin $\mathrm{C}$ membentuk askorbat besi kompleks yang larut dan mudah diserap oleh organ-organ pada tubuh manusia. Pengubahan zat besi non-heme dalam bentuk senyawa metabolis Ferri menjadi Ferro akan semakin besar bila ph di dalam lambung semakin asam. Vitamin $\mathrm{C}$ dapat menambah keasaman sehingga membantu meningkatkan penyerapan zat besi sebanyak $30 \%$.Selain penting untuk kesehatan mata, vitamin A juga penting untuk meningkatkan jumlah sel darah merah.Vitamin A membantu dalam mobilisasi zat besi untuk dimasukkan ke dalam hemoglobin untuk mengangkut oksigen. Mineral, tembaga dan fosfor berperan dalam memelihara kesehatan dan fungsi sel darah merah. Tembaga membantu dalam metabolisme zat besi sedangkan fosfor membantu hemoglobin dalam pengiriman oksigen ke jaringan tubuh $^{15}$.

Kurma matang kaya akan kandungan kalsium dan besi, penting dalam proses pembentukan air susu ibu. Kurma mampu menambah kuantitas ASI dan bayi yang disusuinya akan berotak cerdas serta bersifat baik. Kadar zat besi dan kalsium dapat menggantikan tenaga ibu yang terkuras saat melahirkan atau menyusui.Zat besi dan kalsium merupakan dua unsur efektif yang penting untuk pembentukan darah dan sumsum tulang ${ }^{16}$.

Menurut Hammad(2014), manfaat kurma bagi kesehatan adalah untuk mengatasi anemia (kurang darah) karena kurma mengandung kadar zat besi yang tinggi ${ }^{17}$.

Anemia juga dipengaruhi secara langsung oleh konsumsi makanan sehari-hari yang mengandung zat besi, untuk meningkatkan kadar hb maka diperlukan konsumsi makanan yang mengandung zat besi salah satunya dengan mengkonsumsi kurma. Kurma dapat digunakan sebagai pengobatan berbagai macam penyakit.Salah satu manfaat kurma adalah sebagai bahan pengobatan pada anemia dan penyakit demam berdarah. Kandungan zat besi dalam kurma dapat digunakan untuk pengobatan anemia. Adanya zat besi dalam kurma nantinya diserap oleh usus dan dibawa oleh darah untuk hemopoiesis (proses pembentukan darah). Zat besi akan berikatan dengan heme dan globin, yang nantinya membentuk satu kesatuan menjadi hemoglobin. Sehingga, secara tidak langsung kurma dapat membantu menambah hemoglobin sampai ke angka normal bagi penderita anemia ${ }^{18}$.

Menurut penelitian Pitasari (2017), setelah dilakukan penerapan mengkonsumsi jus jambu biji merah selama 15 hari, terbukti kadar hemoglobin ibu post partum meningkat dengan nilai rata-rata $\mathrm{HB} 1,4$ $\mathrm{g} \%$.

Menurut penelitian Ningtyastuti dan Suryani (2018), dari hasil uji statistik diperoleh hasil ada pengaruh mengkonsumsi jambu biji merah terhadap peningkatan kadar hemoglobin ibu hamil di Kelurahan Bandung Kecamatan Ngrampal Kabupaten Sragen dengan uji wilxocon diperoleh nilai $p$-value sebesar $0,002(\alpha=0,05)$. Dengan kesimpulan ada pengaruh mengkonsumsi jambu biji merah terhadap peningkatan kadar hemoglobin ibu hamil di Kelurahan Bandung Kecamatan Ngrampal Kabupaten Sragen ${ }^{20}$.

Hasil penelitian Putri (2017), rata-rata peningkatan kadar hemoglobin pretest dan 
postest pada kelompok kontrol yaitu 11,06 dan 11,29, dan peningkatan kadar hemoglobin pretest dan posttest pada kelompok perlakuan yaitu 10,23 dan 11,6 sehingga terdapat perbedaan kenaikan kadar hemoglobin pada kelompok kontrol dan kelompok perlakuan dimana nilai ratarata selisih kadar hemoglobin sebelum dan sesudah pada kelompok perlakuan yaitu 0,66 , dan rata-rata selisih kadar hemoglobin sebelum dan sesudah pada kelompok kontrol yaitu 0,23 dengan nilai $\mathrm{p}$-value $=$ $0,026<\alpha(0,05)$. Kesimpulannya adalah ada pengaruh jus jambu biji terhadap perubahan kadar hemoglobin pada ibu hamil trimester III yang megkonsumsi tablet $\mathrm{Fe}$ di Puskesmas Pakualaman Yogyakarta $^{21}$.

Menurut penelitian Susilowati (2017), ada pengaruh pemberian buah kurma pada ibu hamil terhadap kenaikan kadar hemoglobin dengan rata-rata kenaikan kadar hemoglobin sebesar $1,1 \%$, dengan nilai signifikan sebesar $0,001^{22}$.

Menurut Setiowati dan Nuriah (2019), responden yang diberikan sari kurma sebagian besar mengalami peningkatan kadar hemoglobin. Hal ini dibuktikan dengan terjadinya peningkatan kadar hemoglobin ibu hamil pada saat sebelum diberikan sari kurma sebagian besar mengalami kadar hemoglobin tidak normal, setelah diberikan sari kurma terdapat peningkatan kadar hemoglobin yaitu hampir seluruh responden mengalami peningkatan kadar hemoglobin. Dengan kesimpulan ada pengaruh sari kurma (Phoenix Dactylifera) terhadap peningkatan kadar hemoglobin ibu hamil trimester III di Wilayah Kerja Puskesmas Batulicin ${ }^{23}$.

Tujuan penelitian ini yaitu untuk mengetahui pengaruh pemberian jus jambu biji merah dan kurma terhadap peningkatan kadar $\mathrm{Hb}$ pada ibu post partum di BPM Yosephine Palembang Tahun 2019.

\section{METODE PENELITIAN}

Variabel dalam penelitian ini yaitu jus jambu biji merah dan kurma sebagai variabel independen, dan peningkatan kadar $\mathrm{Hb}$ ibu post partum sebagai variabel dependen. Penelitian ini menggunakan desain penelitian pre experiment dengan pendekatan one group pre-test post-test. Teknik pengambilan sampel menggunakan Non probability sampling dengan carapurposive sampling sesuai dengan kriteria inklusi dan eksklusi. Jumlah sampel yang diambil sebanyak 15 responden. Tempat penelitian dilaksanakan di BPM Yosephine Palembang. Waktu penelitian ini dilakukan pada bulan April-Juni 2019.Teknik pengumpulan data yang digunakan dalam penelitian ini adalah data primer yaitu data yang diperoleh langsung dari responden yang diteliti. Instrumen pengumpulan data yang digunakan dalam penelitian ini adalah checklist dan lembar observasi. Penelitian ini dilakukan dengan mendapat izin dari BPM Yosephine dan meminta persetujuan kepada responden menggunakan lembar Informed consent. Pengelolaan dan analisis data dilakukan dengan menggunakan uji Paired T-Test.

Prosedur kerja pada penelitian ini dengan cara ibu nifas dilakukan pemeriksaan kadar $\mathrm{Hb}$ terlebih dahulu sebelum diberikan perlakuan. Jika kadar $\mathrm{Hb}$ ibunya masuk dalam karakteristik anemia ringan dan sedang maka diberikan jus jambu biji merah dan kurma. Jus jambu biji merah dan kurma ini diberikan pada ibu nifas yang anemia 1x sehari selama 2 minggu atau 14 hari. Hari ke 15 kita lakukan pemeriksaan $\mathrm{Hb}$ kembali, apakah ada peningkatan kadar $\mathrm{Hb}$ atau tidak.

\section{HASILPENELITIAN}

Karakteristik responden berdasarkan tingkat anemia. Penelitian ini dilakukan pada 15 responden ibu post partum yang anemia dan diberikan jus jambu biji merah 
ISSN: 2503-1392

e-ISSN: 2620-5424

dan kurma 1x/hari selama 14 hari dengan hasil ukur yaitu anemia ringan 9-10 gr\%

dan anemia sedang 7-8 gr\%, dan dapat dilihat pada tabel dibawah ini:

Tabel 1. Distribusi frekuensi tingkat anemia

\begin{tabular}{lll}
\hline Anemia pada ibu post partum & Frekuensi & Persentase \\
\hline Anemia ringan & 11 & $73,3 \%$ \\
Anemia sedang & 4 & $26,7 \%$ \\
\hline Total & $\mathbf{1 5}$ & $\mathbf{1 0 0 \%}$ \\
\hline
\end{tabular}

Berdasarkan Tabel 1 diketahui dari 15 responden ibu post partum didapatkan ibu dengan anemia ringan sebanyak 11 responden $(73,3 \%)$ dan anemia sedang 4 responden $(26,7 \%)$.

Analisis Univariat Peningkatan Kadar $\mathrm{Hb}$, penelitian ini dilakukan untuk mengetahui peningkatan kadar $\mathrm{Hb}$ sesudah diberikan jus jambu biji merah dan kurma pada ibu post partum

Tabel 2. Distribusi frekuensi berdasarkan peningkatan kadar Hemoglobin

\begin{tabular}{lll}
\hline Kadar Hemoglobin & Frekuensi & Persentase \\
\hline Meningkat & 15 & $100 \%$ \\
Tidak meningkat & 0 & $0 \%$ \\
\hline Total & $\mathbf{1 5}$ & $\mathbf{1 0 0 \%}$ \\
\hline
\end{tabular}

Berdasarkan Tabel 2 diketahui dari 15 responden ibu post partum yang anemia diberikan jus jambu biji merah dan kurma semua responden mengalami peningkatan kadar $\mathrm{Hb}(100 \%)$.

Analisis bivariat pengaruh pemberian jus jambu biji merah dan kurma terhadap peningkatan kadar $\mathrm{Hb}$ pada ibu post partum, analisis ini digunakan untuk membandingkan kadar $\mathrm{Hb}$ sebelum dan sesudah diberikan jus jambu biji merah dan kurma. Uji statistik yang digunakan adalah $t$-test dengan batas kemaknaan, bilap-value $<0,05$ artinya ada hubungan yang bermakna (signifikan) dan bila $p$ value $>0,05$ berarti tidak ada hubungan yang bermakna.

Tabel 3.Pengaruh pemberian jus jambu biji merah dan kurma terhadap peningkatan kadar Hb pada ibu post partum

\begin{tabular}{lllll}
\hline Kadar Hemoglobin & Mean & Standar Deviasi & $\boldsymbol{p}$ value & $\mathbf{N}$ \\
\hline Sebelum & 9,34 & 0,810 & 0,000 & 15 \\
Sesudah & 10,24 & 1,099 & & \\
\hline
\end{tabular}

Berdasarkan tabel3 menunjukkan bahwa dari 15 responden nilai rata-rata sebelum diberikan jus jambu biji merah dan kurma yaitu 9,34 gr\% dengan standar deviasi 0,810, dan nilai rata-rata sesudah diberikan jus jambu biji merah dan kurma yaitu 10,24 gr\% dengan standar deviasi 1,099. Setelah diberikan jus jambu biji merah dan kurma $\mathrm{Hb}$ ibu post partum mengalami peningkatan kadar $\mathrm{Hb} 0,9$ gr\%.
Hasil uji statistik diperoleh nilai p-value $0,000 \leq 0,05$ yang berarti ada pegaruh pemberian jus jambu biji merah dan kurma pada ibu post partum.

\section{PEMBAHASAN}

Analisis univariat peningkatan kadar HB, Dari tabel 2 diketahui 15 responden ibu post partum yang anemia diberikan jus jambu biji merah dan kurma ada peningkatan kadar $\mathrm{Hb}$ 
sebanyak 15 responden (100\%). Hal ini sesuai dengan teori Muslihah (2010), yang menyatakan kandungan mineral yang ada dalam buah jambu biji dapat mengatasi penderita anemia (kekurangan darah merah) karena didalam buah jambu biji merah mengandung juga zat mineral yang dapat memperlancar proses pembentukan hemoglobin sel darah merah. Menurut Hammad (2014), buah kurma dapat mengatasi anemia (kurang darah) karena kurma mengandung kadar zat besi yang tinggi ${ }^{12,17}$.

Berdasarkan penelitian dilapangan didapatkan ibu post partum yang anemia banyak merasa lelah, lemah, mata berkunang-kunang. Hal ini sesuai dengan teori Proverawati and Asfuah (2009), tanda dan gejala anemia adalah keluhan lemah, pucat, mudah pingsan, sementara tensi masih dalam batas normal (perlu dicurigai anemia defisiensi), mengalami malnutrisi, cepat lelah, sering pusing, mata berkunangkunang, lidah luka, nafsu makanturun (anoreksia), konsentrasi hilang, nafas pendek (pada anemia parah) ${ }^{6}$.

Analisis bivariat pengaruh pemberian jus jambu biji merah dan kurma, berdasarkan tabel 3 hasil uji statistik menggunakan uji $\mathrm{T}$ didapatkan nilai $p$-value $0,000 \leq 0,05$ yang berarti ada pegaruh pemberian jus jambu biji merah dan kurma pada ibu post partum. Hal ini sesuai dengan teori Muslihah (2010), yang menyatakan kandungan mineral yang ada dalam buah jambu biji dapat mengatasi penderita anemia (kekurangan darah merah) karena didalam buah jambu biji merah mengandung juga zat mineral yang dapat memperlancar proses pembentukan hemoglobin sel darah merah. Menurut Hammad (2014), buah kurma dapat mengatasi anemia (kurang darah) karena kurma mengandung kadar zat besi yang tinggi $i^{12,17}$.

Penelitian ini hasilnya sama dengan penelitian Pitasari (2017), setelah dilakukan penerapan mengkonsumsi jus jambu biji merah selama 15 hari, terbukti kadar hemoglobin ibu post partum meningkat dengan nilai rata-rata $\mathrm{HB} 1,4 \mathrm{~g} \%$. Dengan kesimpulan mengkonsumsi jus jambu biji merah terbukti efektif mampu meningkatkan kadar hemoglobin pada ibu post partum. Menurut Susilowati (2017), ada pengaruh pemberian buah kurma pada ibu hamil terhadap kenaikan kadar hemoglobin dengan rata-rata kenaikan kadar hemoglobin sebesar $1,1 \%$, dengan nilai signifikan sebesar 0,001 . Hal ini menunjukkan adanya pengaruh kenaikan kadar hemoglobin dengan pemberian buah kurma ${ }^{19,22}$.

\section{KESIMPULAN}

Distribusi frekuensi berdasarkanpeningkatan kadar Hemoglobin setelah pemberian jus jambu biji merah dan kurma pada ibu post partum mengalami peningkatan kadar $\mathrm{Hb} 15$ responden (100\%). Ada pengaruh pemberian jus jambu biji merah dan kurma terhadap peningkatan kadar $\mathrm{Hb}$ pada ibu post partum dengan nilai kenaikan kadar $\mathrm{Hb} 0,9 \mathrm{gr} \%$.

Diharapkan untuk ibu post partum yang anemia untuk mengkonsumsi jus jambu biji merah dan kurma secara rutin agar dapat meningkatkan kadar $\mathrm{Hb}$ dalam tubuh.

\section{DAFTAR PUSTAKA}

1. World Health Organization (WHO).2017.

2. Kemenkes RI. 2016.Pelayanan Kesehatan Ibu di Fasilitas Dasar dan Rujukan.

3. Dinas Kesehatan Sumatera Selatan. 2015. Profil Kesehatan Sumatera Selatan. Dinas Kesehatan Sumatera Selatan. Palembang.

4. Dinas Kesehatan Kota Palembang. 2017. ProfilKesehatan Kota Palembang. Dinas Kesehatan Kota Palembang. Palembang.

5. Tarwoto, N. dan Wasnida. 2007.Buku Saku Anemia Pada Ibu Hamil, Konsep Dan Penatalaksanaan. Trans Info 
Media. Jakarta.

6. Proverawati, A. dan Asfuah, S. 2009.Gizi Untuk Kebidanan. Nuha Medika. Yogyakarta.

7. Departemen Gizi dan Kesehatan Masyarakat. 2011.Gizi dan Kesehatan Masyarakat.Rajawali Pers. Jakarta.

8. Pearce, E. C. 2009. Anatomi Dan Fisiologi Paramedis. Gramedia. Jakarta.

9. Bahiyatun. 2009.Buku Ajar Asuhan Kebidanan Nifas Normal.EGC. Jakarta.

10. Robson, S. E. dan Waugh, J. 2011. Patologi Pada Kehamilan: Manajemen \& Asuhan Kebidanan. EGC. Jakarta.

11. Prawirohardjo, Sarwono. 2007.Ilmu Kandungan.Yayasan Bina Pustaka Sarwono Prawirohardjo. Jakarta.

12. Muslihah. 2010.Tanaman Obat Keluarga. Penebar Swadaya. Jakarta.

13. Parimin. 2005.Jambu Biji: Budi Daya Dan Ragam Pemanfaatannya.Penebar Swadaya. Jakarta.

14. Cahyono, Bambang. 2010.Sukses Budidaya Jambu Biji Di Pekarangan Dan Perkebunan.Lily Publisher. Yogyakarta.

15. Sianturi, C. 2012.Pengaruh Vitamin $C$ pada Penyerapan Zat Besi Non Heme. FMIPA UNM. Medan.

16. Rostita. 2009.Khasiat dan Keajaiban Kurma. Qanita Mizan Pustaka. Bandung.

17. Hammad, S. 2014.Kedokteran Nabi. Pt Aqwam Profetika. Solo.

18. Sari. 2013.Manfaat Buah Kurma. Home Health. Yogyakarta.

19. Pitasari, R. N. 2017.Karya Tulis Ilmiah Pengaruh Mengkonsumsi Jus Jambu Biji Merah Terhadap Peningkatan Kadar Hemoglobin Pada Ibu Post Partum.http://elib.stikesmuhgombong.ac .id/445/1/RATNA\%20NUR\%2OPITASAR I\%20NIM.\%20B1401204.pdf. Diakses tanggal 13 Februari 2019.

20. Ningtyastuti, Yeri Esty dan Suryani, E. 2018. Pengaruh Mengkonsumsi Jambu Biji Merah Terhadap Peningkatan Kadar Hemoglobin Ibu Hamil. Jurnak
Kebidanan Indonesia. 6 (2): 61-68.

21. Putri, Andiyani Nurul. 2017.Pengaruh Jus Jambu Biji Terhadap Kadar Hemoglobin Ibu Hamil Trimester Iii Yang Mengkonsumsi Tablet Fe.http://digilib.unisayogya.ac.id/2647/1 /ANDIYANI\%20NURUL\%2OPUTRI\%20 \%28naskah\%20publikasi\%29.pdf. Diakses tanggal 13 Februari 2019.

22. Susilowati, Diyah Ayu. 2017.Pengaruh Pemberian Buah Kurma Pada Ibu Hamil TM III Dengan Anemia Terhadap Kadar Hemoglobin Di Bpm Tri Rahayu Setyaningsih Cangkringan SlemaEn Yogyakarta.http://digilib.unisayogya.ac. id/2685/1/NASKAH\%2OPUBLIKASI_\% 20Diyah\%20ayu\%20susilowati.pdf. Diak ses tanggal 13 Februari 2019.

23. Setiowati, W. dan Nuriah, S. 2018.Pengaruh Sari Kurma (Phoenix Dactylifera)Terhadap Peningkatan Kadar Hemoglobinibu Hamil Trimester III. Jurnal Kesehatan STIKES Darul Azhar Batulicin. 6(1): 85-91. 